\title{
Mytholinguistic Interpretation of Sacral Toponym Astana in Sociocultural Practice of the Siberian Tatars
}

\author{
Irina Sovetovna Karabulatova ${ }^{1} \&$ Flera Sagitovna Sayfulina ${ }^{2}$ \\ ${ }^{1}$ Institute of Social and Political Research of Russian Academy of Sciences, Moscow, Russian Federation \\ ${ }^{2}$ Kazan Federal University, Kazan, Russian Federation \\ Correspondence: Irina Sovetovna Karabulatova, Institute of Social and Political Research of Russian Academy \\ of Sciences, Leninsky Prospect 32a, 119991 Moscow, Russian Federation. E-mail: radogost2000@mail.ru
}

\author{
Received: August 26, 2014 Accepted: November 6, 2014 Online Published: February 12, 2015 \\ doi:10.5539/ass.v11n5p303 URL: http://dx.doi.org/10.5539/ass.v11n5p303
}

\begin{abstract}
Siberia takes a special place among the regions of Russian Federation; its population has its own mentality, unique historical past, moral and economic consciousness. The authors fix their attention on the specificity of mythologized consciousness of the Siberian Tatars in order to reveal the places of Sufi views and stories about Astana.
\end{abstract}

Today we agree that the name, as a bundle of psycho-energetic forces of the ethnos, has a doubtless influence on the evolution of history in whole, forming the collective unconscious, promoting the consolidation of the archetypical images force to perceive yourself integrally. Modern onomastics leaves the interpretation of the proper name exclusively under the frames of etymology. As a rule, the basis can be presented by imagery, metaphor-metonymic processes, lying in the basis of denomination of specific denotations and lexical background, i.e. the combination of information, referring to the named object. In this connection, mental space of the proper name presents a special interest, because, functioning in polyethnic environment, all elements of regional onomastic system are subject to the influence of perception-stereotyped standards, peculiar of a man, as a knower.

Saint places of the Siberian Tatars, Astana, take one of the central places in traditional sociocultural practice of the Siberian Turki. Astana complexes themselves present the material implementation of the Sufism idea about implicit knowledge communication. Siberia was associated and is still associated with some mythological space, where the reality, forgotten by the civilized world, is the actuality, where the world edges come in touch with each other, where the heroes live and act, that is why this space is marked by the special sacral places - Astana, which offer a clue to understand Sufism among the Siberian Tatar. The stories about Astana were published by N. F. Katanov. The stories themselves were written in variants: the first version - by Saad Vakkas, the son of Radjab, Allakulov, and the other - by Kashshaf Abu-Said. At present, these notes are kept in Tobolsk Regional Museum of Local Lore and are available for the researchers.

The researchers pay special attention to the significance of Sufism in traditional views of the Siberian Tatars, fairly underlying, that Sufism has a lot of directions. The authors tend to think that worship practice to Astana is conditioned by Sufism, equally as the manuscript literature of the Siberian Tatars, reflecting the ethno-sociocultural practice of the Siberian Tatars.

Oral folk arts always presented that ideologic and artistic property of people, where they could express their outlook and attitude to life. According to the data of folkloristics, which counts nearly one and a half centuries, the Siberian Tatars has a rich folk-poetic heritage, including different genres of the oral folk arts. Unfortunately, in the flow of time, there are less and less opportunities left to collect and record the folklore pieces, as they go into wilderness together with their bearers, oldsters. Fortunately, a great volume of folklore material was collected and studied so far, based on which is possible to make several conclusions. As a result of folklore-dialectological expeditions of scientists from Tobolsk, Kazan and Tyumen, there were written the stories about Astana, among which the following are distinguished: 1) the stories, telling about conservative-protecting function of Astana; 2) the stories, telling about wonderful curing energy of Astana; 3) the stories about vindictive force and power of Astana spirits. Many Sufi folk tales about santons and legends of the Siberian Tatars about Astana have similar episodes. These plots tell about miraculous power of sheiks: mind 
reading, curing of the ill, control of nature and jinns, movement by air and water etc. According to Sufi ideas, the man's spirit presents the man's essence, and the body is only the ash. If you die, you will be mourned by your children, but only Tengere (the God) will know your essence. At present, the Kazan and Tyumen researchers carry out a meticulous work to certificate all Siberian Astana.

Keywords: mythology, linguistics, interpretation, Islam, Sufism, toponymy, Astana, Siberia, Siberian Tatars, Arabs, toponymic stories

\section{Introduction}

A toponymic space, existing in the consciousness of regional inhabitants, is much greater in volume than the toponymical space of the map, as the small geographical objects are important for those, who live in the region, but they are of no interest for people beyond the limits of the region, for large-scale maps etc. Modern toponymical reality is "the unfolding" manifestation of organizing potential, at that, mind is used as a toponymical strategy and intention is used as a power, which is required to change, choose, form, modify and organize the initial patterns. When any of the enumerated actions is made, the information fields and the semantic aura of the toponym are changed. These changes necessitate the changes in the material plan. That is why the researchers fairly state that "a myth is one of the peculiarities of onomastic discourse" (Karabulatova, Fedorova, \& Saifulina, 2013, p. 1134).

In Siberian folklore, one of the central places is taken by the stories about Astana, as about places of burial and worship to sheiks, who brought Islam to Siberia. In mythologized consciousness of Siberian Turki, these sheiks belong to Arabia or to Bukhara, what testifies, on the one hand, about merging of different centers of Islam culture in ethnocultural consciousness of the Siberian Tatars, and, on the other hand, about rather high degree of mythologization of the Arabic culture in representations of the Siberian Tatars. Alongside with that, in the ethnogenesis of the Siberian Tatars, a definite place is taken by the Bukhara descents, whose descendants (even if they are mixed with local Siberian Turki) are named Bukhartsy by the Siberian Tatars.

In this connection, it is necessary to pay attention to the fact that the stories about sheiks' life are of great interest; they are connected with Islam extensionists in Siberia. There are two manuscripts in the library of Tobolsk Museum of Local Lore (volume is 3 and 4 pages), named "About Religious Wars of Scholars of Bagauddin Sheik against Non-Russians of the Eastern Siberia". One of them is written by Saad Vakkas, son of Radjab, Allakulov, and the other - by Kashshaf Abu-Saidov. The content of both manuscripts is almost identical, they differ only in insignificant details.

These manuscripts were translated into Russian by N. F. Katanov; the translation was published in 1903 in "Scholarly Notes of the Kazan University" (Katanov, 1903, pp. 133-146), and in 1904 in "Annual Publication of the Tobolsk Governorate Museum" issue 14 (Katanov, 1904, pp. 3-28).

The text narrates about the trip of 366 Muslim preachers from dervish Naqshbandiyah order and 1700 warriors to Western Siberia to convert local people into Islam: "As per Muslim chronology, 797 anno Hegirae (started on October 27, 1394 and ended on October 15, 1395) became a year, full of real friendship with Islam...". It contained the whole history of missioners, began in "Holy Bukhara" in the times of Abu-l-Leysa khan "by volition" of founder of the mystic order "Nakshbandiya" ishan Hodge Bagau-l-khakk-ua-d-din. When arriving to Siberia, the sheiks began to execute his order relatively the Islam outspreading. It is considered that 300 from 366 sheiks died; 3 prophets stayed among the Siberians, teaching them usul ad-din, 63 returned to Bukhara, where they informed Bagau-l-khakk-ua-d-din of the executed task. The document also enumerates 29 sacral buries - Astana.

It is traditionally considered that Sufism is a mystical-ascetic direction in Sunni Islam; it appeared approximately in the VIII-IX century and was finally formed by the XII century. Sufism is an integral part of Islam, and it is interpreted as a way of catharsis (nafs) from bad qualities and inoculation of meritable qualities to the spirit (rukh) (Yakhin, 2002).

There are no doubts, that this way is difficult for the followers, that is why a pupil - murid ("searching", "desirous") takes it under direct supervision of the teacher - murshid ("a spiritual advisor"), who reached the end of the Way and got the appropriate permit for mentoring (iddzhaza) from his murshid. Thus, we see the oral communication of sacral knowledge.

Sufis showed bright radicalism in educational practice, aimed at depreciation of murid personality. For instance, "murid shall feel himself in front of sheik, as a deader in front of the one, who washes him", "who said "no" to the sheik, that man would not succeed", "who contradicts, will be read out". Such murshid (Sufi sheik, ustaz) is a part of the sheik chain, which goes up to Muhammad prophet. The one, who does not have iddzhaza from his 
sheik to teach murids, is not a real sheik and does not have a right to teach Sufism to desirous (tassavvfu, tariqa). Sending or the way to Siberia in national consciousness is equal to the travel to sacral world of Death, to the Other world, that is why the travel of Sufis to Siberia was connected with the trial of human spirit, being favorable for murid school. Everything, that contradicts Shariat, is not Sufism; it was mentioned by the outstanding Sufi sheik Imam Rabbani (Akhmad Sirkhindy, Akhmad Faruk) in "Maktubat" ("Letters") (Saifullina \& Talipova, 2010). It shall be mentioned that some Sufis criticized the concept of isnad, which is based on getting the information through the whole chain of transmitters, considering, that only oral communication from teacher to pupil provides the correct understanding of Islam (Yakhin, 2000). For instance, Sufis said: my heart communicated me from the God. According to their point of view, Sufi directly communicates with the God. "You get information through the deaders, and we get it from the Alive, Eternal", said Sufis about those, who got knowledge through the books. Sufis have the idea that "intuition" and "taste" present the basis of legislation. According to this idea, the person can be supported by his intuition and taste when making laws.

Such trends destroyed psychic and the spiritual state of many Muslims. The ideas of fatalism and negativism got great development in their way of thinking, resulting in social inactivity, indifferent relation to the cause vice, tyranny, breach of justice and abnormal phenomena, Sufis' preference of that ruler, who permits them the rituals, contradicting Islam, to that ruler, who prohibits them. All this is a result of Sufism extremes. These moods are also traced in Sufi manuscript literature of Siberian Tatars (Saifullina \& others, 2013).

For a long time Siberia was considered an inordinate place for human spirit, a place for human soul trial, that is why, it is not for nothing that the Sufi groups were sent to Siberia. The toponym Siberia itself was familiar to Arabic scientists of antiquity (Karabulatova, 2008; Saifullina \& others, 2013).

\section{Materials and Methods}

Proper field survey of the authors both among the Siberian Tatars and in different archives of Tobolsk became the materials for this article. For instance, the medieval book "Bakyrgan Kitaby" ("The Bakyrgan Book"), popular among the Siberian-Tatar population, which unites the works of Sufi poets of the XII-XVIII centuries, includes 18 poems of the poet Ikany. Up to the end of XX century, nothing was known about the author of the poems. He was mentioned neither in the lists of Sufi-sheiks, nor in the encyclopedic dictionaries of Eastern famous scientists of the last centuries of the East. However, in the abovementioned publication of N. F. Katanov "About Religious Wars of the Scholars of Bagauddin Sheik against Non-Russians of the Eastern Siberia", based on two Tatar manuscripts of the Tobolsk Museum, which, alongside with the names of another sheiks preaching Islam in these regions, mention about the mausoleum of "honorable sheik Aikany/lkany", situated in "Isker".

A manuscript, translated by N. F. Katanov, is a sachara of one of Astana guardians. For a long period of time, it was the only and earliest documental source on Islamisation of Siberia, introduced into scientific use.

The last discoveries (a protograph of genealogic tree of the Siberian-Tatar saints (sächäre/ chäzhärä in Arabic graphics), one of the lists was published by N. F. Katanov as a body of Sufi texts), founded by the historian, regional investigator I. V. Belich in the village Karagay of Vagaysk district of Tuymen region in summer of 2004, read by the literary critic F. Z. Yakhin, strengthened our suppositions (Belich, 2004). According to the data of so called "Karagaysk Scroll", the scientist came to conclusion that it is the poet Ikany, presented as the author of the poems, included to "Bakyrgan Kitaby", who was one of 366 sheiks, arriving on Siberian ground in 1394 in order to outspread Islam among native people. Supported by the content of this valuable historical discovery, it is possible to assure that the poet was buried on the shore of Irtysh river (Abu-Dzhirs) (Yakhin, 2006). Unfortunately, there is no another data about this poet Ikany. Thus, we can suppose that the poet Ikany is the author of 18 extant poems; he is one of the sheiks, who were "armed with the belief to Allah" and the only desire to help others to learn Islam. Indirect proof can be found in his works. Earlier, I. V. Belich mentioned that there is some information about sacral places - Astana - in the legends of the Siberian Tatars (Belich, 1997).

The name Ikany, in our opinion, is the author's proper name. It is translated as "Imanly ("A Person with Belief"). All his familiar poems were written under the influence of the author's Sufi views (Yakhin, 2006, p. 189). Analyzing the poems of the poet Ikany, mainly devoted to revelation of Sufism ideas, quite outspread in Medieval times, there were found some more facts, proving, although indirectly, our suppositions. It is necessary to note that Sufism is the main direction in Medieval literature. As a literary direction, Sufism was outspread among nations, who followed Islam. Ascetic moods, generated the origin of Sufism in the Volga Region, appeared together with adoption of Islam in the VIII-IX centuries. The name Sufi belonged to those Muslim mystics, who wore clothes of rough wool, as a symbol of self-denial and confession, showing that they differ 
from those, who is lapped in luxury. The Orientalist A. Sibgatullina points at 9 meanings of the word "Sufi" (Sibgatullina, 2000, p. 7).

There are several opinions about Sufism origin: for instance, in the opinion of Khorasan theologian and Sufi Kusheiry (986-1076), the term "Sufi" appeared in the beginning of the IX century. It is often stated that the first Sufi was Abu Khashim from Kufa, died in 778. In the opinion of Persian-Tadjik scientist Abu Raykhan Biruny (973-1048), the word "Sufi" comes from the Greek word "sofos" - "wisdom" (khikmet). In Russian philosophy, the problems of Sufism are considered in the work of E.E. Bertels "Sufism and Sufi Literature" (1965). E. E. Bertels considers that Sufism appeared after the death of the third Khalif (Osman), as a result of power struggle between the fourth khalif (Ali) and Muafy. Betels proves that Sufism has an Islamic origin and denies a viewpoint of French school, stating that Sufism is a product of Christianity. Adam Mets in his book "Muslim Renaissance" (1973) states that Sufism appeared in Egypt, in "the nurse of Christian monkhood".

There are different trends in the history of Sufi views development in literature, which differ in their ultimate variety. Many scientists state that, essentially, there was no unified Sufism. It was promoted by the development of society, appearance of different brotherhoods. However, all served to one great aim, they were united by the one - improvement of human spiritual world. Sufis proclaimed their devotion to the Prophet's apprenticeship. The rituals and traditional belief were of no importance for them as compared to the God itself, who stays only in "pure heart". Sufis reflected over the meaning of Koran poems, strictly followed the orders and Sunna of the Prophet, prayed a lot, kept a fast, kept a cult of poverty and labor for catharsis. Deep analysis of finest human feelings is a distinctive feature of Sufis, as their main purpose is the ascent to the Truth.

The numerous legends and stories about missionaries Sufis and places of their burial - astana, collected by the national folklorist A. Niyazov, name these sheiks and describe their deeds and the attitude of the Siberian-Tatar nation. For instance, the legend, written by him as "The Deeds, that would be Made by the Sheik Bizeley" ("Pisäläy-chyk pelgän echläpe ") narrates, that this sheik was very literate and had a magic power. He cured from different diseases with his power, made different evil spirits serve him. A place near the village Kaynaul, where Bizeley Sheik was buried, is named popularly a sacral place until now. These materials, collected in the period from 1993 to 1995 by Askhat Niyazov are kept in the archives of the Department of Tatar Language, Literature and Teaching Methodology of the Tobolsk State Social-Pedagogical Academy named after D. I. Mendeleev.

Cult documents - sachara - the manuscripts in the form of roll, written in Arabic graphics, were preserved from the documental sources, connected with Sufi sheiks. All this created the sacral-ritual mythological discourse of sacral places of the Siberian Turki - Astana. In this poly-aspect space of myths about Astana, everything works: the places themselves, burial grounds, manuscript rolls of guardians of these places, manuscript books of Sufi sheiks, the stories of local population about miracles, connected with Astana, modern regional fiction, including regional mythology.

\section{Results}

Rhymed denomination of Siberia in Arabic sources is connected, from our point of view, with the denomination of prohibited, closed place, remote area, with brightly expressed negative connotation. Such correlation of the toponym Siberia in national linguistic conscience with the sacral place moves Siberia itself to the reality of the myth, intensifying the significance of this space for Sufi practice, as the Sufism is a vivid practice of Islam (Yakhin, 2000). In this connection, Astana as a word, having only one repeated vowel, stands into one row with "sacral" words.

Astana denote not only the burial places of Sufi sheiks, arrived some time ago on Siberian ground. The meanings of Astana are much wider and volumetric for the Siberian-Tatar culture. The name Ikany is distinguished among the names of Sufis, who brought the knowledge of Islam. Ikany's Astana is mentioned in the abovementioned work of N.F. Katanov, kept in Tobolsk. It shall be noted that these people, buried in these Astana, were rather unusual for that times, they were in advance of their epoch. Reading and analysis of their creative work provides understanding of it. For instance, in "The Bakyrgan Book", consisting of 143 lyrical-philosophical and lyrical-epical pieces, the poems from ninety to one hundred and eight belong to the poet Ikany. The poems are written in Turkic-Tatar language with wide use of Sufi-religious terminology from Arabic-Persian languages. 298 lines of Ikany's poems make up 142 poems. Although this reading book was published several times in Kazan, starting from 1847, they were underinvestigated, and they were not analyzed in literary-artistic plan. in Soviet times, the book was not published, only in 2000 "The Bakyrgan Book" saw the light in Kazan.

The Siberian-Tatar work "sachara" (shagerelshagaralsecheralsachara) denotes a genealogic tree, tree of life. These genealogic trees were used to prove the right for the plots of land, when the Russian population came to Siberia, and they frequently presented the main symbol of Astana guardian - the burial places of saint sheiks, 
who propagated Islam in these regions. Sachara were usually inherited, and, it was considered that its guardians (Astana karautsy) were the descendants of the sheik generation (shyk tugum). In Soviet period, in the time of strict antireligious policy, the majority of Sachara was lost. The remaining documents, as a rule, were kept in strict secret, even first-degree family did not know about their existence.

Sachara are extremely important for investigations, as, being rewritten from generation to generation, they testify about the distribution of literacy among the Siberian-Tatar population. Besides, these genealogic trees are the documents, illustrating the immediate connection with different Islamic nations. In the course of historical development, borrowed samples, words, cults and rituals are overgrown with the original system of associative fields, syncretically uniting different cultures.

Due to abovementioned, the interpretations and explanations of the word "astana" are of great interest. In many Siberian-Tatar villages, the burial places of the missioners, Islam supporters, so called "astana", were preserved up to the present days.

In Sufism (tasavvuf), astana is determined as a place, where the "saint" and preachers lived, and where their mausoleums exist, to which the pilgrimage (ziyara) is fulfilled. For a mystic, it is connected with the purpose to achieve the spiritual communication (murakaba) with the saint, and for a layman - to get intercession, thanks to his spiritual power (baraka), able to do miracles (Belich, 2006, p. 14).

It shall be noted that the main Tengriism doctrines, including a cult of ancestors, provided the basis for tradition of holy burial places worship - Astana. The first Islamic missioners were the representatives of Sufism, and the Sufism demonstrated a wonderful plasticity, ability to soak up traditional folk beliefs and representations and to return them to people in Muslimanized form (Seleznev \& Selezneva, 2004, p. 4). These places are considered sacred for the Siberian Muslims. A respect for these places was passed from generation to generation; the legends, connected with their activity, play a great role in it. Until now, a lot of legends, connected with the names of sheiks, their teachings and burial places, are popularly kept.

People go to mazars to recite offices. "Monta keshe doga kylypga kiläte, kirtmälärneng altty möyshende kömesh akcha kaltyrat - people come here to pray, they leave silver coins in six corners of timber crib".

People believe, that they have curing power. It is considered, that here it is prohibited to foul, evil deeds and intensions in astana are punishable: "...One Russian, on purpose, with bad motives, set a hexagonal crib of astana on fire. The very next day he took sick and died within one month. That summer, his children died one after another. One of his sons, suffering from dying agony for two days, told: "Our father committed a great sin, tell the others not to do in this way". Sufi's cry is a catharsis, an opportunity to get mental and spiritual purity (Goff 1991).

In the collected materials, there are such texts, describing, how several tractor drivers destroyed the astana, ploughed the soil. They got the same punishment: all died or sustained injuries.

In these cases, as is popularly told, the astana owners - buried sheiks "leave, move" to another places. The stories where the sheiks, whose peace was disquieted by people, came in dreams to some villagers are frequently met. For instance, a woman, who told about this event, states, that it was a dream of her father. It was like this: once that land, where the saints were rested, was bought by the Russians, that is why the saints moved to another, calmer place.

The Siberian Tatars express the veneration of confessors - avliya - with magi orientation. It is met not only in oral legends, but also in written sources. In N. F. Katanov's translation, there is a compellation: "Kindly ask you to protect the sacred tombs at all times...for the sheiks not to be furious and not to bring scandal upon them and their generations!"

If to compare the materials of these legends and stories, collected by A. Niyazov, then many names and places coincide with the list, left by N. Katanov. For instance, the astana of Khakim sheik is in Baesh, the astana of Kasim sheik is in Vagay, the astana of Bigyach-ata sheik is in Big Buryans, the astana of Khadidzh bibi and Akyl bibi sheiks is in Yurmakh, the astana of Salikh bibi sheik is in Saurgach and others. The names of other sheiks are met in legends, however their existence is not proved documentarily, but this fact does not derogate their significance before people.

\section{Discussion}

Within the whole range of centenaries, Sufism was the object of serious attention on the part of philosophers, historians, philologers of East and West. Sufism problems are studied in numerous works of Tatar scientists and literary critics of the XIX century, such as A. Kursavy, G. U.-Imyany, S. Mardzhany, and also of the beginning 
of XX century - G. Gubaidullin, G. Rakhim and others. The study of this direction was especially activated in the second half of the XX century. Different aspects of Sufism in whole and the impact of its ideas in Tatar literature, in particular, are considered in the works of U. Belyaeva, Kh. Mukhammetov, Kh. Khismatullin (1963), M. Gaynullin (1968), A. Sharipov (2001), Kh. Minnegulov (1967), R. Ganieva (1988), A. Sibgatullina (2000), F. Yakhin (2000-2006).

Among all nations and in all times, there existed an idea about secret, special, higher form of knowledge, available to a person only after passing the difficult living circumstances and definite tests on the way of moral perfection. The same is Sufism - secret teaching, aimed at Truth perception in order to raise a person at higher degree of perfection. The highest purpose of Sufism is to comprehend the God and to perceive the Truth (Backman 2002).

In the opinion of F. Z. Yakhin, one of the main ideas in the pieces of Ikany is connected with Sufi philosophy "zikr". Many works of literary critics mention, that in Sufi literature, the notion "zikr" is the main and very significant. In scientific works, this term is interpreted as a Sufi praying to the God. However, direct understanding of this term narrows its deep meaning. It is impossible to limit "zikr" by the praying, even pleading, repetition of names of the Holy Allah; in case of such understanding, it is possible neither to understand the meaning of Sufi "zikr", nor to understand the content of Sufi philosophy.

Judging by his poems, the poet Ikany understands "zikr" as not only a religious-ritual action. He supposes that an important condition for "zikr" is human affection. The God, in Sufi understanding, is "Khak, i.e. "Khakyikat" ("Truth"). Judging by the content of poet's poems, we can say, that Ikany considers: "The absolute truth" is not worth searching outside the man himself, on the side. The truth, as well as the belief to Allah, is kept in the soul of the man himself. In the opinion of the poet, "zikr" is an appeal to the God, it purifies the human soul to perceive the absolute truth.

Sometimes in the poems, instead of the word "zikr", Ikany uses the Turkic variant of this notion - "yad kylu", what means "to remember, to bear in memory". However, for Sufis to "remember the God" is not just "to bear it in memory". Memory, human mental abilities for Sufis are just the material status. Human memory for Ikany is not a constant category, it is variable. It is impossible to be founded on it, it is not everlasting. The poet considers this human quality to be "earthy, but not everlasting". As everything earthy is temporal, frail for Sufis, and everything heaven is eternal, from here follows that the place of "Absolute truth" is not a human memory, but his soul, as it is the soul, that is eternal and deathless. Thus, Ikany states that the God shall be remembered, understood and perceived not by the mind, but by the soul. "When praying, recollect the God's name with all your heart, if you want, you can name it when sitting or lying on your side". The professor F. Z. Yakhin mentions, that "the notion "lying on your side" means not idleness, but dream. Alongside with that, in Ikany's poems, the word "joky" ("dream") is mainly used in negative meaning. Sleepy man for the poet is "gafil", i.e. illiterate. It is known that "awakening" in Sufi understanding is a transition from material into spiritual world. Ikany repeatedly writes that "to remember about the God, to bear him in soul is not just a religious observance, but a definite state of mind of the spiritual man in everyday life.

Dating of Islamisation beginning in Siberia is a discussive topic among the investigators up to the present times. Some consider that thanks to the diplomats and travelers from Muslim countries, the population of Western Siberia got acquainted with Islam from the X century (Valeyev, 1976; 1992). The others connect it with the Uzbek khan's declaration of Islam a state religion of the Golden Horde (first half of XIV c.). The third connect it with Kuchum khan (second half of the XVI c.). Some consider, that even in the XVIII century, a part of Siberian Tatars did not adopt Islam yet. However, the majority of investigators, thanks to publication of N. F. Katanov consider the end of XIV century as a time of arrival of the first Islam missioners (Robinson, 2003).

"Veneration of sheiks and study of their life, pilgrimage to the tombs of missioners, the institute of mausoleum guardians, morality tales in folklore of Siberian Tatars, similar in style and plot to the legends of travelling sheiks, preserved even after their death, belief in dreams, as a bridge between the worldly and spiritual, lectures-adabs, present the link of Sufism and traditional Islam of Siberian Tatars" (Rakhimov, 2006, p. 29).

\section{Conclusions}

Thus, the folklore material can serve as a useful source to study the history, ethnography, language, customs and rites of the nation. Careful attitude towards everything, belonging to national history, his past, the study of these materials, can provide the science with interesting results. 
Many Sufi folk tales about Muslim saints and the legends of Siberian Tatars contain similar episodes, telling about miraculous power of sheiks: mind reading, curing of the ill, control of nature and jinns, movement by air and water etc.

The Siberian-Tatar nation also has oral prosaic stories, referring to stories, which narrate about the events of remote past. These plots are based on real facts, which, after so many years, evoke different gossips and rumors, thus causing the additional interest. There were preserved a lot of toponymical stories, telling the origin of different geographical names: rivers, lakes, mountains and others. They provide precise data, i.e. the authentic explanations of one or another name, proven by practice or historical data. Another type of stories is presented by historically unsupportable, disputable poetic explanation of one or another name, however, it is interesting in its content, literary imagery and language. Those stories are very curious, that tell about the origin of Tatars of such population centers, as Achiry, Laimtamak, Neshshe, Nosky of Tobolsk region, Sopra, Ishair, Katanguy of Vagaysk district of Tuymen region, Leshakovo, Tyurmetyaky, Ashevany of Ust-Ishiminsky district of Omsk region.

As distinct from the stories, the legends are based not on the real facts, but on fictive narration, which is presented by the narrator as the very truth. Fiction in legends is not the way of breadth, but it's content. Siberian-Tatar legends "Green Women" and "About a Revolt of Three Hundred of Disobedient Women", written by A. Niyazov, were published in translation into Russian by the writer-historian Vyacheslav Safronov in the magazine "Idel". Here the author provides a high evaluation to the collectors of folk art and writes: "...we got used, that our history takes place somewhere in other regions, and we consider our nuggets as brood, mercilessly throwing them from memory" (Safronov, 1993, p. 53). The same stories were used by Y. Zankiev in his novels "The Dawns of Irtysh" and "Aflamed Love" (Zankiev, 1994). These novels correlate with the idea of Sufism about the divine love, where Sufism is transformed from the methodology of "spiritual-moral upbringing" to the philosophy, containing another new, foreign to Islam, conceptual notions, anomalies and breakaway from fundamental Islam principles (Zankiev, 1994; Sadykov, 1998).

Thus, we can state that the mythological interpretation of sacral complexes of Astana, recorded in public conscience of the Siberian Tatar, reflects the psycho-cosmos of the Siberian Tatar, conditioned by syncretism of paganism of the Siberian Tatars and official religious Islam practice. The outspread of this phenomenon exists both in folklore of the Siberian Tatars, manuscript medieval literary sources, and in modern fiction of the region. All this forms the regional and ethnical identity.

A German political scientist A. Neumann fairly noticed that "...the identity is not a givenness, but a relation, constantly formed and reformed under the definite discourse" (Neumann, 1993). That is why the artistic perception of the territory in mythological-folklore creative work of the Siberian Tatars presents a discourse, more adequate for understanding of formation of regional identity as a process.

\section{References}

Backman, C. R. (2002). The World of Medieval Europe (p. 480). Oxford University Press, USA.

Belich, I. V. (1997). The Khan Cemetery. Siberian Capital (pp. 55-73). Tobolsk.

Belich, I. V. (2004). Methodological and Methodical Aspects of Investigation of the Siberian Tatars' Astana. Integration of Archeological and Ethnographical Studies (pp. 38-41). Almaty-Omsk.

Belyaeva, U., Mukhammetov, Kh., \& Khismatullina, Kh. (1963). Modern Tatar Literature (p. 578). Kazan.

Ganieva, R. K. (1988). Eastern Renaissance and a Poet Kul Galy (p. 173). Kazan, KSU Publisher.

Gaynullin, M. (1968). Tatar Literature. 19 Century (pp. 27-63, 218-229). Kazan, Magarif.

Goff Le, J. (1991). Medieval Civilization (1st ed., p. 448). Blackwell Publishing.

Karabulatova, I. S. (2008). Prognostic Toponymy: Transformation of Toponymic Space in Linguistic Consciousness of Russian Native Speakers (p. 254). Tyumen: Pechatnik.

Karabulatova, I. S. (2009). A Sacral Myth of Astana: from a Holy Site of Siberia to Capital Kazakhstan. Finding of the Capital Status by Astana. The Collection of Reports of the International Scientific Conference (pp. 176-185). Astana.

Karabulatova, I. S., Fedorova, E. A., \& Sayfulina, F. S. (2014). A Linguo-Mythological Space of the Toponym "Siberia" in Contemporary Slavonic Linguistic Consciousness. World Applied Sciences Journal. Retrieved June 6, 2014, from http://www.idosi.org/wasj/wasj30\%289\%292014.htm

Katanov, N. F. (1897). The Legends of Tobolsk Tatars about Arrival of Muhammad Preachers to Isker in 1572. 
Annual Publication of Tobolsk Governorate Museum. Tobolsk, 7, 51-61.

Katanov, N. F. (1903). About Religious Wars of Scholars of Bagauddin Sheik against Non-Russians of the Eastern Siberia. Scholarly Notes of the Kazan University, Book 12, 133-146.

Katanov, N. F. (1904). About Religious Wars of Scholars of Bagauddin Sheik against Non-Russians of the Eastern Siberia. Annual Publication of Tobolsk Governorate Museum, Tobolsk: A Typography of Brotherhood Episcopate (Issue XIV).

Mets, A. (1973). Muslim Renaissance. Moscow.

Minnegulov, Kh. Yu. (1976). Saif Saray. Life and Creative Work (p. 189). Kazan.

Neumann, I. B. (1993). Russia as Central Europe's Constituting Other. East European Politics and Societies, 7(2), 349-369. http://dx.doi.org/10.1177/0888325493007002006

Rakhimov, R. Kh. (2006). Astana in the History of the Siberian Tatars (p. 76). Tyumen: Pechatnik.

Rakhimova, A. (2001). Lexicology of Dialects of the Siberian Tatars (p. 128). Kazan: Master Line.

Robinson, F. (2003). Islam and Muslim History (p. 310). OUP India, Oxford.

Sadykov, K. S. (1998). Reflection of Customs, Rites, Traditions of the Siberian Tatars in the Novel "The Dawns of Irtysh" by Ya. Zankiev. Life and Creative Work of Pedagogue and Writer Ya.K. Zankiev. In the Proceedings of Regional Scientific-Practical Conference (pp. 33-37). Tobolsk.

Safronov, V. (1993). Green Women, About the Revolt of Three Hundred of Disobedient Women. Idel, 4, 53.

Saifullina, F. S., \& Talipova, G. M. (2010). The Work of Amdamy "Nasikhatname" in the Context of Sufi Medieval Literature. A Herald of Bashkir University: Philology and Art History, 15(1), 124-127.

Sayfulina, F. S., Karabulatova, I. S., Yusupov, F. Yu., \& Gumerov, I. G. (2013). Contemporary Issues of Textual Analysis of Turkic-Tatar Literary Monuments of Western Siberia. World Applied Sciences Journal, 27(Education, law, economics, language and communication), 492-496. IDOSI Publications.

Seleznev, A. G., \& Selezneva, I. A. (2004). Siberian Islam: Regional Variant of Religious Syncretism. Novosibirsk.

Sharipov, A. M. (2001). Origin and Development of Poetic Genre System in Old Turkic and Turkic-Tatar Literature: (VIII-XIY Centuries) (p. 364). Kazan: KSU.

Sibgatullina, A. T. (2000). Tatar Literature and Sufism. In Sufis of the Volga Region: Stories and Sources (pp. 66-75). Kazan.

Valeev, F. T. (1976). On the Religious Ideas of the Siberian Tatars. Nature and Man in the Religious Ideas of the Peoples of Siberia and the North (pp. 320-331). Leningrad, Nauka,

Valeev, F. T. (1993). Siberian Tatars: Culture and Everyday Life (pp. 149-150). Kazan, Magarif.

Yakhin, F. Z. (2000). Religious Mystics and Mythology in Tatar Poetry (M. S. thesis, p. 50). Kazan.

Yakhin, F. Z. (2002). Tobolsk Tatar Poet Amdamy and his Work "Nasikhatname" (Book of Lectures) (pp. 601-602). Turkic Nations. Cultural Heritage of Nations of the Western Siberia.

Yakhin, F. Z. (2006). Sufi Ideas in the Creative Work of Shaikh Ikany. Education and Culture as a Factor of Regional Development. In the Proceedings of All-Russian Mendeleev Readings, Devoted to 90 years of Tobolsk Teacher's Institute (p. 189). Tobolsk: TSPI.

Zankiev, Ya. K. (1994). Dawns of Irtysh (p. 671). Kazan.

\section{Copyrights}

Copyright for this article is retained by the author(s), with first publication rights granted to the journal.

This is an open-access article distributed under the terms and conditions of the Creative Commons Attribution license (http://creativecommons.org/licenses/by/3.0/) 